NOTE XXXI.

\title{
DESCRIPTIONS OF NEW GENERA AND SPECIES OF PHYTOPHAGOUS COLEOPTERA
}

COLLECTED BY

Dr. B. HAGEN at Serdang (East Sumatra).

BY

MAŔTIN JACOBY.

Criocerina.

Lema homatomelas, Lac.

The Sumatran specimens before me, belong with one exception to the var. a. of Lacordaire, in which the underside and the antennae are entirely fulvous; in these specimens, not only the anterior legs, as Lacordaire's description says, but all are of the same colour. The species seems to vary greatly in this respect, the underside, legs and antennae being either fulvous or black. - I may further add to the author's description that there is a more or less distinct trace of another transverse thoracic depression anteriorly in all the specimens which have come under my observation and which is frequently the case in other species from the eastern parts of the world.

Lema palpalis, Lin.

A single specimen of this species, which is also found Notes from the Leyden Museum, Vol. VI. 
in Java and India, is contained in the present collection. The shape of the palpi, which have their terminal joint distinctly swollen, distinguishes well the present insect.

$$
\begin{aligned}
& \text { Lema fulvula, Lac.? } \\
& \gg \text { coromandeliana?, Lac. }
\end{aligned}
$$

The single specimen which was obtained by Dr. Hagen agrees very nearly with the $L$. fulvula, which, together with many other varieties, has been united by Mr. Baly under the name of $L$. coromandeliana Lac. In the insect before me, the underside (with the exception of the apex of the abdomen) is black as well as the lower part of the head, the antennae (the basal joint excepted) and the tibiae and tarsi; all the rest is fulvous. So far this agrees with Lacordaire's description; the differences are however the following: the entire head is covered with close and yellow pubescence and there is a total absence of the frontal elevations, very distinct in $L$. coromandeliana (as also agreeing with the author's description), the thorax instead of being "lisse" has 2 fine but distinct rows of punctures; without more specimens for comparison I am not able to say whether the insect before me is Lacordaire's species or a new one.

\section{Eaumolpince.}

\section{Callisina integricollis, n. sp.}

Oblong-ovate, subcylindrical, reddish fulvous; legs and antennae (their 3 basal joints excepted) black; thorax finely punctured, sides not dentate; elytra finely punctatestriate. - Length 2 lines.

Head swollen at the vertex, deeply punctured at the sides above the eyes; epistome separated from the face by a deeply punctured oblique groove, its anterior margin concave-emarginate; jaws black; antennae dilated and widened at the terminal joints, 3 lower ones fulvous, the

Notes from the Leyden Museum, Vol. VI. 
rest black (the 2 last joints wanting); thorax subcylindrical, a little broader than long, lateral margin very slightly sinuate at the middle; surface remotely and finely punctured at the disk, the sides more closely and strongly punctured; a deep transverse narrow groove extends immediately behind the anterior margin across the disk; scutellum elongate, semi-triangular; elytra finely punctatestriate, the shoulders prominent, immediately within the latter and below the base a deep depression is seen, on account of which the basal portion seems strongly raised; a very distinct tubercle is placed immediately below the shoulder, extending in shape of a short costa to the sides; inner side of the femora stained with fulvous, armed with a minute tooth.

The single specimen before me does not differ in structural characters from the other 2 species of this genus, except in the entire, not dentate, sides of the thorax and in the more cylindrical shape of the latter.

\section{Aoria nigripes, Baly.}

This insect, of which a single specimen was obtained by Dr. Hagen, has not been previously recorded from the Eastern Archipelago, Mr. Baly's specimens having been captured at Hongkong; these specimens do not differ from the Sumatran form.

$$
\begin{gathered}
\text { Rhyparida pinguis, Baly. } \\
\text { ovalis?, }
\end{gathered}
$$

I do not think that the two species described under the above names are specifically distinct, as fulvous and piceous coloured specimens from the same locality are contained in the present collection which I am not able to separate otherwise. The elytra in this species are longitudinally sulcate throughout, by which character the insect may be principally known, but the margin of the thoracic episternum is not concave (characteristic of Rhyparida) but

Notes from the Leyden Museum, Vol. VI, 
convex; the insect had therefore be placed better in the genus Phytorus Jacoby. (Ann. Mus. Genoa. XX. 1884). It is possible that the species described under this name by myself is but the male form of the present insect.

Abirus subrugosus, n. sp.

Metallic green; head finely and closely punctured, semipubescent; antennae dark violaceous blue, the last five joints strongly dilated; thorax. strongly and closely punctured; elytra finely and regularly punctate-striate at the inuer disk, strongly transversely rugose at the sides. - Length 4 lines.

Head somewhat swollen, very closely and finely punctured; middle of the front with an obsolete longitudinal groove, sparingly covered with fulvous pubescence; epistome not separated from the front, a little more strongly punctured than the latter, its anterior margin slightly concaveemarginate; labrum metallic green ; antennae half the length of the body, the first joint metallic green, the following violaceous, last 5 joints very strongly dilated and flattened; thorax transversely convex, strongly deflexed at the sides, all the angles with a distinct tubercle, surface closely and evenly covered throughout with oblong deep punctures, rather more strongly impressed at the sides than at the disk; scutellum distinctly broader than long, violaceous; elytra subcylindrical; distinctly depressed below the base, the latter having a somewhat raised appearance, the entire inner half of their disk is finely and regularly punctate-striate, the outer portion strongly transversely strigose; these elevated strigae assume towards the apex the shape of single irregular tubercles which are placed on a slightly raised longitudinal ridge; under surface sparingly clothed with fulvous pubescence.

This species, of which but a single specimen is before me, differs from A. (Dermorhytis) elegans Baly in the very regular punctuation of the inner disk of the elytra, the

Notes from the Leyden Museum, Vol. VI. 
punctuation being also very fine, not coarse; the epistome is also finely punctured and the elytral interspaces are not raised near the apex.

\section{Corynodes basalis, n. sp.}

Metallic green with brassy reflections; last 5 joints of antennae dilated, purplish blue; head and thorax strongly punctured; elytra deeply depressed within and below the basilar space, rather finely, closely and regularly punctatestriate. - Length $4 !_{2}^{1}$ lines.

O. Elytra with a single sublateral costa from the middle to the apex.

Head very deeply and strongly punctured, the punctuation much more closely arranged at the vertex than towards the lower portion and at the former place of oblong shape; epistome separated from the face by a deep transverse groove, the space immediately above the latter covered with coarse dark fulvous pubescence in the middle of which an oblong small tubercle is placed; epistome broader than long, closely rugose-punctate; labrum obscure metallic green; antennae less than half the length of the body, the first joint metallic green, the $\mathbf{5}$ following joints obscure dark fulvous stained with metallic green; the 5 terminal ones dilated, purplish blue; thorax transversely convex, the sides moderately deflexed anteriorly, the lateral margin rounded from the middle to the apex; anterior angles acutely produced; surface impressed with deep punctures which are only somewhat closely placed anteriorly, the base and sides being only punctured here and there; elytra with a deep transverse depression below the base and within the shoulders, the basal portion distinctly raised and very finely punctured, rest of the surface regularly punctate-striate, distinctly visible to the apex; tibiae dilated and mucronate at the apex; claws appendiculate.

Closely allied, to C. approximans Baly, of which the present species may possibly be a variety; the dilated joints

Notes from the Leyden Museum, Vol. VI. 
of the antennae are however black, not blue, in the allied insect, the antennae in $C$. basalis are not two thirds the length of the body but much shorter and the elytral punctuation is very regular; in the female insect the elytral costa begins below the middle and is abbreviated before the apex; in C. approximans it is described as extending to the sutural margin.

The types of Mr. Baly's numerous species of Corynodes are contained in the collection of the British Museum, with all of which I have compared the species described here.

\section{Chrysochus Hageni, n. sp.}

Oblong-ovate, convex; entirely dark metallic blue; antennae black, first joint metallic green; thorax closely and finely punctured; elytra closely punctate-striate. - Length $3-4^{1 / 2}$ lines.

Head closely punctured, with a central deep longitudinal groove; inner margin of the eyes surrounded by a metallic green narrow space; antennae half the length of the body, the first joint metallic green, the two following ones fulvous, the rest black; thorax nearly twice as broad as long, the sides straight, slightly rounded in front, surface distinctly and closely punctured; elytra transversely impressed before the middle, very closely punctate-striate, the punctures more strongly at the sides than at the disk, the interstices slightly wrinkled anteriorly.

This species is closely allied to C. pulcher Baly, but differs in its entirely metallic blue colour and in the much less coarsely and more closely punctured thorax; the latter, in the female, is of rather more transverse shape than in the other sex.

\section{Malticince.}

Aphthona sumatrana, n. sp.

Black; legs, basal joints of the antennae and the thoNotes from the Leyden Museum, Vol. VI. 
rax testaceous; head dark metallic green; elytra closely punctured, metallic greenish aeneous; posterior femora piceous. - Length $11 / 4$ line.

Head smooth, impunctate; frontal tubercles in shape of a narrow transverse ridge; carina acutely raised; antennae two thirds the length of the body, the third joint scarcely longer than the second, 3 lower ones fulvous, the rest piceous or black; thoraz transversely subquadrate, the sides straight, obliquely shaped at the posterior angles, the anterior ones acute, surface impunctate, fulvous or testaceous (in one of the 3 specimens with a metallic greenish gloss), scutellum and elytra dark metallic green, the latter very closely, finely but distinctly punctured; posterior tibiae piceous, rest of the legs testaceous; posterior tibiae mucronate, their first tarsal joint as long as the 2 following joints together.

\section{Anicera, nov่. gen.}

Body oblong; eyes large, convex, entire; palpi slender, filiform; antennae elongate, rather robust, the second and third joints very short, equal, fourth joint longer than the 3 preceeding ones together; thorax transverse, without any depressions; scutellum triangular; elytra oblong, semipunctate-striate, their epipleurae indistinct below the middle; posterior femora moderately thickened, their tibiae straight, not channelled and unarmed; posterior first 'tarsal joint rather longer than the two following ones united; claws appendiculate; prosternum extremely narrow; mesosternum elongate, its apex pointed; anterior coxal cavities closed.

This genus seems to be an intermediate form between Chaloenus and Oxygona and having the general appearance of the latter; the structure of the antennae, in which the second and third joints are very short, will separate the present genus from either. Sutrea Baly, which also resembles in shape and coloration the genus here proposed, is at once distin-

Notes from the Leyden Museum, Vol. VI. 
guished by the open coxal cavities and different structure of the antennae. A single species is before me.

\section{Anicera bimaculata, n. sp.}

Testaceous; upper part of the head, antennae, the breast, tibiae and tarsi black; thorax testaceous; elytra closely punctured, black, a rounded spot at the middle of each elytron pale fulvous. - Length 2 lines.

Head impunctate at the vertex, the latter black; frontal tubercles transverse, limited behind by a deep groove; clypeus triangular, testaceous; labrum, jaws and palpi piceous; antennae two thirds the length of the body, pubescent, black, the 3 lower joints testaceous, fourth joint the longest, somewhat widened towards the apex like the following joints; thorax of equal width, about twice as broad as long, the sides straight, the angles produced in a very short tooth, surface not visibly punctured; scutellum black, impunctate; elytra black, finely and closely punctured, the punctuation arranged in close longitudinal rows which get more indistinct towards the apex; at the middle of the disk of each elytron a rounded flavous spot is placed; a more or less distinct transverse depression is seen below the base; breast, tibiae and tarsi black or piceous; femora testaceous; abdomen more or less of the latter colour.

Two specimens: one from Sumatra: Highlands of $\mathrm{Pa}-$ dang (Ludeking), the other from Java: Ardjoeno (Hekmeyer).

In the specimen from Java the elytra have a slightly rugose appearance.

\section{Sebaethe sumatrana, n. sp.}

Ovate; obscure piceous below; above pale fulvous; antennae black, the first 2 joints fulvous; thorax impunctate; elytra finely punctured. - Length 2 lines.

Head with a deep transverse groove between the eyes; frontal tubercles broad, distinct and nearly contiguous; carina short and acute; antennae less than half the length 
of the body, the intermediate joints slightly flattened and widened, third joint scarcely longer than the second; thorax about twice as broad as long, the sides rounded and narrowly margined; surface entirely impunctate; at each side near the basal margin an obsolete oblique depression is seen; elytra very finely and closely punctured, the interstices very finely wrinkled' near the sides, the latter also accompained by a more or less distinctly impressed longitudinal groove from the shoulder to the apex; legs piceous or black; underside obscure fulvous or piceous.

The species described here is closely allied to S. badia Erichs. and S. flava Clark, from both of which it differs in its smaller size and colour of the antennae; S. nigricornis Baly is another closely allied species in which however the third joint of the antennae is twice the length of the second; the thorax also is much more transverse and the legs are fulvous.

\section{Sebaethe affinis, n. sp.}

Oblong-ovate, convex, pale fulvous or testaceous; antennae (the first 3 joints excepted) black; thorax scarcely visibly, ely tra very finely punctured. - Length $3-3^{1} / 2$ lines.

Head impunctate, transversely grooved between the eyes; frontal tubercles transverse, very flat and nearly contiguous; carina short and thick; palpi incrassate, the terminal joint acute and conical; antennae not quite extending to half the length of the body, black, the first 3 joints fulrous; third joint twice as long as the second; thorax transverse, more than twice as broad as long, the sides rounded and narrowly margined, the anterior angles thickened; surface microscopically finely punctured; scutellum broad, impunctate; elytra slightly wider at the base than the thorax, very little widened below the middle and rather convex, more distinctly punctured than the thorax; prosternum very distinct, shallowly longitudinally channelled; legs covered with thin yellowish pubescence; posterior

Notes from the Leyden Museum, Vol. VI. 
tibiae curved, deeply longitudinally excavated; posterior first tarsal joint double as long as the two following united.

This species seems closely allied to S. badia Erichs. and S. flava Clark, from both of which it differs in the colour of the antennae which is the same in the 12 specimens before me. From $S$. nigricornis Baly the species differs in its much larger size and the more distinct punctation of its elytra; it is also found in Java.

\section{Eucycla varipes, n. sp.}

Rotundate-ovate, convex, obscure piceous or fulvous below; above fulvous; antennae black, the 3 basal and the apical joint fulvous; legs piceous or fulvous; thorax finely punctured; elytra closely punctate-striate. - Length 2 lines.

Head longer than broad, impunctate, the frontal tubercles almost contiguous and limited behind by a transverse groove; carina acutely raised; labrum piceous; palpi fulrous; antennae about half the length of the body, the first 3 joints fulvous, second and third joint of equal length, the following slightly thickened, terminal joint elongate with a short conical appendage, fulvous; thorax transverse, more than twice as broad as long, widened at the middle, the posterior margin distinctly sinuate at each side, the median lobe rounded and produced; sides with a narrow margin, nearly straight; anterior angles oblique and thickened; surface very closely and finely punctured; elytra closely. and distinctly punctate-striate, the -striae rather obsolete at the disk and near the lateral margin arranged in one or two double rows, the space in front and parallel with the lateral margin, impunctate, the latter itself accompained by a row of deep punctures which are situated within a narrow but deep groove; elytral epipleurae broadly concave.

The genus Eucycla was founded by Mr. Baly on 2 insects from the East, having the appearance of a species of Sphaeroderma; in the types the eyes are extremely large,

Notes from the Leyden Museum, Vol. VI. 
occupying nearly the entire sides of the head, and the clypeus ends in a triangularly shaped point extending between the eyes; the first joint of the antennae is long and slender, the other joints are partially short.

The present species differs rather from the others described by Mr. Baly in having the eyes smaller and the antennae shorter; the general shape is also less rounded and more elongate although not to a great extend; the structural characters are however all present. I may further add, that the elytral punctured striae in the allied species are much wider apart than is the case with the species described here of which 5 specimens where obtained by Dr. Hagen.

\section{Homelea, nov. gen.}

Body rotundate-ovate, convex; eyes entire; palpi thin, filiform; antennae slender, filiform, first joint elongate, second short, third joint twice as long as the preceeding, the following more elongate; thorax narrowly transverse, anterior and posterior margin parallel, semicircular; scutellum trigonate; elytra subhæmispherical, irregularly punctured; their epipleurae broad, deeply concave and disappearing below the middle; posterior femora very slightly incrassate; tibiae unarmed, without sulcation; posterior first tarsal joint as long as the two following ones together; claws appendiculate; prosternum narrow but distinct, longitudinally sulcate; mesosternum deeply emarginate at the apex, narrowly trausverse; anterior coxal cavities closed.

The general appearance of the species for which the present genus is proposed, is quite that of a species of Coccinellae; the posterior femora are but little incrassate although more so than is the case with the Galerucinae; the inner margin of the elytral epipleurae is placed very far inwards; from the genus Acrocrypta Baly, which resembles the present in shape, the filiform palpi and the shape of the posterior femora will at once separate the genus before us, which seems to be a form of transition between the Galerucinae and the present family.

Notes from the Leyden Museum, Vol. VI. 


\section{Homelea variabilis, n. sp.}

Pale fulvous below; above black, shining; lower part of the face and the antennae testaceous; thorax scarcely visibly, elytra closely and distinctly punctured. - Length 2-3 lines.

var. a. Thorax with a black spot at the base, elytra with 5 spots (2.2.1). - Moeara Laboe (Sum. Exp.).

var. b. Entirely fulvous. - Snepajang and Alahan pandjang (Sum. Exp.).

Head impunctate, with a central rounded forea between the eyes; frontal tubercles absent; epistome triangular; labrum transverse, testaceous; antennae about half the length of the body, testaceous; thorax of equal width, the anterior margin deeply concave, the sides straight; anterior angles slightly thickened and obtusely rounded, fulvous; surface impunctate in the male, impressed with a few fine punctures in the female; elytra obsoletely transversely depressed below the base, very distinctly and closely punctured; black, shining; entire underside and the legs fulvous or testaceous.

I can find no other differences in the varieties but those of colour and have considered therefore all the specimens to represent the same species.

\section{Galerucince.}

Aulacophora cornuta, Baly.

The description given of this species by Mr. Baly in the Cistula 1879 agrees perfectly with the Sumatran insects now before me; several similarly and closely allied forrus inhabit Asia and the Malayan Archipelago as well as Australia and the South Sea Islands. The present species (ot which the male insect was only known to Mr. Baly and whose specimens were obtained in India) is distinguished by the peculiar formation of the face in the male and the structure of the first joint of the antennae; in the female the epistome is simple, flat and with a central elevated

Notes from the Leyden Museum, Vol. VI. 
ridge and the antennae are of normal construction; in both sexes the third and fourth joints of the latter are nearly equal; amongst the specimens from Sumatra several varieties occur in which the legs are either partially or entirely fulvous as well as the underside while others agree with the typical form (black underside and legs). $A$. $f a-$ vipes Jacoby is smaller, the last abdominal segment is fulvous and the antennae in the male are of different construction.

\section{Aulacophora 6-punctata?, Oliv.}

All the specimens obtained by Dr. Hagen differ from Olivier's species in having the entire base of the elytra to the extend of their first third black as well as the legs; other specimens have fulvous elytra with a black spot below the middle; as it is quite possible that this species is very variable in regard to colour, I have abstained in describing it as new, although it may be possibly distinct from the one described by Olivier since the 10 specimens before me all agree with each other, with the exception of one or two which have the anterior legs fulvous, thus indicating intermediate degrees of colour.

I am unable to determine with certainty the following speeies:

\section{Aulacophora sp?}

Black; antennae flavous; head and thorax fulvous; elytra black, finely and closely punctured; anterior legs obscure dark fulvous. - Length 4 lines.

$\sigma^{7}$. Third joint of the antennae elongate and the longest, the following short and semitriangularly shaped, terminal joint dilated at the middle into a tooth.

ค. Antennae simple.

This insect does not quite agree with either of the many similarly coloured species described by different authors on account of the structure of the antennae in the male in connection with the black underside and legs.

Notes from the Leyden Museum, Vol. VI. 


\section{Pseudocophora uniplagiata, n. sp.}

Oblong-ovate; below black; above and the anterior legs fulvous; thorax deeply transversely sulcate; elytra semipunctate-striate with a sutural rounded piceous spot below the base. - Length 3 lines.

$\sigma^{7}$. Elytra deeply excavated below the scutellum, the excavation limited in front by 2 strongly raised tubercles.

Head impunctate, deeply transversely grooved between the eyes; frontal tubercles transverse, trigonate; carina acute; antennae half the length of the body, testaceous, second joint short, third joint one half longer than the fourth, this and the following ones equal; thorax twice as broad as long, the sides rounded and widened before the middle, from there to the base straight; anterior angles thickened and very slightly produced outwards, surface with a deep transverse sulcation immediately below the middle, extending across the entire disk, the latter impunctate with the exception of a few fine punctures near the anterior angles; scutellum trigonate, impunctate, flavous; elytra, slightly widened towards the apex, with numerous irregular double rows of fine punctures which get nearly obsolete near the apex; immediately below the scutellum a large rounded black or piceous spot is placed across the suture, in front of which a deep excavation, bounded at each elytron by a conical fulvous tubercle, is seen in the male; elytral epipleurae continued below the middle; underside and legs (with the exception of the anterior ones) black, shining; claws bifid.

The present genus was founded by myself (Notes from the Leyd. Mus. VI. p. 69) on a species formerly included in Aulacophora, from which it must be separated on account of the prolonged elytral epipleurae; the species here described agrees in every particular with the type except in the coloration; in the allied species the elytra are reddish fulvous, their anterior half and lateral margin being black;

Notes from the Leyden Museum, Vol. VI. 
as I have several specimens of $P$. uniplagiata all agreeing with each other and no intermediate forms, I cannot consider the present species a variety only of $P$. Buqueti. In a specimen contained in my collection, the locality of which I do not know, all the tibiae are fulvous and the elytral tubercles black.

\section{Macrima abdominalis, Jacoby.}

Of this species, which was described by myself in the Notes from the Leyden Museum. (vol. VI. p. 60), I had at that time evidently female specimens only before me. In the present collection the same species is contained in both sexes; the male insect is at once distinguished, by the longer antennae and by the posterior tibiae which are curved and dilated as well as flattened at their middle, their outer edge presenting an acute ridge; nearly all the specimens now before me have fulvous, scarcely punctured elytra (as in the type) but the space surrounding the scutellum is more or less testaceous, in other respect they do not differ. At first sight the species of this genus resemble those of Aulacophora, from which the closed anterior cavities, continued elytral epipleurae and appendiculate claws separate them, which agrees with Mr. Baly's description of the genus.

\section{Macrima subcostata, n. sp.}

Below black; above testaceous; elytra obsoletely longitudinally costate, obscure fuscous, each elytron with a pale longitudinal band from the base to the apex. Length $2 \frac{1}{2}-3$ lines.

$\sigma^{7}$. Antennae with the $3^{\mathrm{d}}$ and $4^{\text {th }}$ joint compressed and widened.

\%. Antennae simple.

Head impunctate; frontal tubercles transverse, narrow,

Notes from the Leyden Museum, Vol. VI, 
limited behind by a deep transverse groove; clypeus thickened, triangular; labrum and palpi testaceous; apex of jaws black; antennae slender, elongate, the first joint very long, slender and curved, thickened at the apex, second joint very short, third dilated and flattened, fourth longer than the third, widened at its base; thorax one half broader than long, narrowed at the base, the sides rounded towards the apex; surface impunctate, with a deep transverse depression not extending quite to the sides and interrupted at the middle by a narrow, short and slightly raised space; scutellum obscure piceous; elytra a little widened posteriorly, closely and very finely punctured, the interstices closely but not strongly longitudinally costate, the costae disappearing below the middle; posterior tibiae mucronate; posterior first tarsal joint as long as the 3 following ones united; claws appendiculate; anterior coxal cavities closed.

The elytra in this species have each a pale longitudinal stripe, more or less distinct, from the base to the apex; the description given above is that of the male insect.

\section{Macrima malayensis, n. sp.}

Breast black; abdomen testaceous; above pale flavous; thorax deeply transversely depressed; elytra finely punctured, shining: - Length $21 / 2-3$ lines.

Head impunctate; antennae two thirds the length of the body, the fourth joint one half longer than the. third; thorax impunctate, impressed as in the preceeding species; elytra finely and closely punctured.

The two specimens before me differ in the colour of the abdomen which is testaceous in one and black with the exception of the last 2 segments in the other; the specimen which I refer to the female sex has a little more strongly punctured elytra, the punctuation being slightly arranged in longitudinal rows, but only seen under a strong lens.

The present species may be distinguished from $M$. abdo-

Notes from the Leyden Museum, Vol. VI. 
minalis by its pale flavous or testaceous colour of its upper surface; it is however possible that it is but a variety of the last named species.

\section{Malacosoma cyanicollis, $\mathbf{n}$. sp.}

Oblong-ovate, dark violaceous; antennae flavous, the first 2 joints piceous; thorax nearly impunctate; elytra fulvous, very finely punctured. - Length 3 lines.

Head impunctate; frontal tubercles flattened, contiguous, bounded behind by a transverse groove; clypeus transverse, thickened; labrum black; apical joint of palpi obscure fulvous; antennae two thirds the length of the body, flavous, the first and the base of the second joint piceous, shining; third joint one half longer than the second; thorax convex, nearly twice as broad as long, the sides rounded, anterior angles thickened and slightly produced; posterior margin a little rounded; surface nearly impunctate, shining, dark violaceous blue, scutellum of the same colour; elytra convex, slightly widened behind, fulvous, very finely and closely punctured, visible only under a strong lens; their epipleurae continued below the middle; all the tibiae with a small spine; first posterior tarsal joint rather shorter than the 2 following united; claws appendiculate; anterior coxal cavities open.

This species has all the structural characters peculiar to Malacosoma but the thorax is more transverse than is generally the case with species of this genis. .

\section{Arcastes suturalis, n. sp.}

Oblong-ovate, fulvous; abdomen, legs and antennae black, the last 2 joints of the latter testaceous; elytra minutely punctured, black, the suture narrowly fulvous below the base. - Length $21 / 2$ lines.

Head fulvous, impunctate, transversely grooved between the eyes; clypeus triangular; antennae more than half the length of the body, the intermediate joints widened and 
compressed, second joint short, this and the preceeding one shining, the others covered with thick pubescence, the two apical ones testaceous; thorax three times as broad as long, the posterior margin rounded; anterior angles slightly thickened, obtuse; surface entirely impunctate, fulvous; scutellum of the same colour; elytra slightly widened at the middle, extremely closely and finely punctured, black or piceous, the suture anteriorly narrowly fulvous, this colour not extending below the middle; femora often fulvous at the base, tibiae and tarsi black.

\section{Sastroides, nov. gen.}

Body broadly ovate, convex, pubescent; eyes large, convex, entire; palpi robust, the fourth joint swollen at the base, its apex broadly rounded; antennae slender, filiform, the second joint very short, third joint extremely long and the longest; thorax transverse, 3 times as broad as long, the sides dilated at the middle, surface with a central and lateral deep depression; scutellum subpentagonal, its apex broadly rounded; elytra dilated behind, closely punctured and pubescent, their epipleurae rather broad and continued to the apex; legs elongate; tibiae obsoletely channelled, their apices unarmed; posterior first tarsal joint as long as the two following ones united; claws bifid; prosternum invisible between the thighs; anterior coxal cavities open.

I am obliged to propose this genus for the reception of a species which is apparently closely allied to the genus Sastra Baly; in the latter however the palpi are slender, the thorax much less transverse and the general shape of the insect is more elongate, while here it is convex and dilated giving the species the appearance of the South American genus Monocesta or Coelomera.

\section{Sastroides bimaculata, n. sp.}

Entirely pale yellowish brown; head finely and closely, Notes from the Leyden Museum, Vol. VI. 
thorax coarsely punctured; elytra opaque, pubescent, each elytron with a small bluish black spot at the middle. Length 4 lines.

Head closely rugosely punctate, with a smooth central longitudinal narrow space extending to the frontal tubercles; the latter very distinct, transversely oblique; clypeus narrowly transverse, thickened; labrum entire; two terminal joints of the palpi swollen and dilated near the apex; antennae rather more than half the length of the body, the first joint curved and thickened near the apex, second joint less than half its size, third nearly double the length of the two preceeding ones united, the following gradually decreasing; thorax three times as broad as long, anterior and posterior margin parallel, straight, the latter obliquely rounded at the sides, these strongly rounded and widened at the middle; surface with a deep transverse depression at each side, interrupted at the middle by another longitudinal more shallow depression which widens at the base; disk closely covered with deep larger. and smaller punctures, shining; scutellum covered with long pubescence; elytra widened behind, narrowly margined, their surface very closely and rather finely punctured and closely covered with pale fulvous pubescence; at the middle and a little nearer the lateral than the sutural margin, is a round bluish black spot; underside and legs shining, pale fulvous or testaceous, claws divided or bifid nearly to their base.

Sastroides unicolor, n. sp.

Entirely pale testaceous; head closely and finely punctured; thorax irregularly and strongly punctured; elytra shining, closely and finely punctured, covered with whitish silky pubescence, their epipleurae narrow. - Length 4 lines.

Head closely and finely rugose-punctate, the punctures divided by a narrow smooth space; palpi less robust than 
in the allied species; clypeus broader and less transverse; labrum piceous; antennae nearly as long as the body, the third joint not much longer than the fourth, the terminal joints more elongate and slender than in the preceeding species; thorax of the same shape as the latter, less strongly punctured; elytra punctured in the same way, more shining, not opaque, the pubescence thinner and white, their epipleurae much narrower and nearly indistinct below the middle.

The structure of the antennae, shape of the thorax and elytra in this species are the same as in S. bimaculata, but the palpi are less robust and the elytral epipleurae much narrower below the shoulder; in all other structural characters it agrees with it; the species is further distinguished from the preceeding one by the unspotted and shining not opaque elytra, the longer antennae and general paler colour which is that of a greyish testaceous.

\section{Menippus Clarki, n. sp.}

Oblong-ovate, obscure flavous below; intermediate joints of the antennae, tibiae and tarsi piceous; above fuscous, closely pubescent; head, thorax and elytra closely punctured. - Length 5 lines.

Head finely rugose-punctate; frontal tubercles indistinct, clypeus transverse; eyes large; antennae less than half the length of the body, three lower and base of the terminal joints testaceous, the rest piceous; third and fourth joints equal, the intermediate ones slightly widened; thorax more than twice as broad as long, the sides dilated and subangular at the middle, surface obsoletely obliquely depressed at each side, closely punctured and pubescent, the interstices finely rugose; scutellum broad, its apex broadly rounded, surface punctured and pubescent; elytra convex, punctured and covered with fine silky hairs like the thorax, obscure dark fulvous or fuscous; tibire and tarsi piceous; claws bifid; coxal cavities closed. 
Antipha bifasciata, n. sp.

Head, breast and tibiae black; antennae, thorax, femora and abdomen testaceous; elytra black, closely punctured, a transverse band before, another below the middle and the lateral margin near the apex, fulvous. - Length 2 lines.

var. Underside testaceous.

Head piceous or black, impunctate, with a deep transverse groove between the eyes; lower part of face obscure dark fulvous; labrum testaceous; antennae two thirds the length of the body, slender, filiform, basal joint curved, thickened at the apex, second joint less than half the size of the preceeding, third and following joints elongate; thorax at least three times as broad as long, the anterior margin concave, posterior one parallel with it; sides nearly straight, the anterior angles slightly produced outwards, flattened and oblique; disk impunctate; scutellum broadly trigonate, black; elytra rather convex, nearly parallel, distivetly punctured, the punctures arranged in rather regular and closely approached rows, distinct to the apex; black; immediately before the middle, a fulvous transverse band is placed which does not quite extend to either margin, this band is narrowed at each end; close to the apex is another more regularly shaped band and extending quite to the lateral and sutural margin; the former near the apex is likewise narrowly fulvous; abdomen and legs testaceous; breast and tibiae piceous; prosternum narrow, closing the anterior coxal cavities.

Antipha seminigra, Jacoby var.

Of this species; described by myself in the Notes from the Leyden Museum (Vol. VI, p. 52) a variety is contained in the present collection in which the entire underside and legs are, pale fulvous and the elytra either black (as in the type) or dark blue; structural characters I can-

Notes from the Leyden Museum, Vol. VI. 
not find to separate these forms from the typical one; the filiform antennae and less rounded and convex shape of the insect separate it from the allied genus Emathea Baly.

\section{Neolepta, nov. gen.}

Body ovate-oblong; head moderately exserted, transversely grooved between the antennae; eyes entire, rather prominent; third joint of maxillary palpi incrassate, terminal joint conical, of nearly the same length; antennae rather robust, pubescent, the intermediate joints flattened and dilated, second and third joints very short, of equal length; thorax transverse, surface with a transverse depression at each side; anterior angles obtusely rounded and slightly thickened; posterior margin rounded, somewhat sinuate at each side; scutellum broadly trigonate; elytra ovate, convex, surface closely punctured and also irregularly punctate-striate, their epipleurae continued below the middle; prosternum not visible; the anterior coxal cavities closed; legs slender, the first posterior tarsal joint longer than the 3 following joints together; posterior tibiae with a long spine; claws appendiculate.

On account of the long first tarsal joint and closed coxal cavities, the genus proposed here is closely allied to the genus Monolepta and still more closely to Candezea Chap. This latter genus was erected on an african insect described by von Harold as a Luperodes; from either of these genera the present is at once separated by the intermediate dilated joints of the antennae and the shortness of their second and third joints.

From Candezea it is further distinguished by the transversely impressed thorax.

Neolepta fulvipennis, n. sp.

Fulvous; antennae, breast and tibiae black; thorax with a few fine punctures; elytra more strongly punctured, the 
punctuation partly arranged in longitudinal rows. - Length 3 lines.

var. Underside entirely fulrous.

Head impunctate, deeply transversely grooved between the eyes; frontal tubercles transverse, nearly contiguous; labrum and palpi black; antennae half the length of the body, the first 3 joints shining, the rest pubescent, black, underside of the basal joint stained with fulvous; thorax finely punctured near the anterior margin and the sides, surface impressed at each side by a sinuate groove, interrupted at the middle; elytra more or less distinctly punctate-striate, the interstices irregularly punctured and slightly rugose; tibiae and breast black; femora more or less piceous or fulrous.

A specimen from the Rawas District (Sum. Exp.) has the entire underside fulvous but differs in no other way.

\section{Neolepta biplagiata', n. sp.}

Below obscure fulvous; head, thorax and first 2 joints of the antennae reddish fulvous; elytra finely and closely punctured, black, the extreme base obscure fulvous, a transverse spot at the middle flavous. - Length $21 / 2$ lines.

Head impunctate, transversely grooved between the eyes; frontal tubercles distinct, transverse; antennae nearly as long as the body, the second and third joints very short, the latter and the following joints closely covered with long hairs, intermediate ones slightly dilated; thorax more transverse than in the preceeding species, extremely finely punctured when seen under a strong lens, disk impressed on either side with a distinct transverse forea; scutellum fulvous; elytra black, closely and slightly rugosely punctured, each elytron with a yellowish white transverse spot, not quite extending to either margin and placed immediately below the middle; tibiae and tarsi piceous, rest of the underside testaceous.

Notes from the Leyden Museum, Vol. VI. 


\section{Eustetha variabilis, n. sp.}

Oblong-ovate; breast, abdomen and posterior legs black; antennae and anterior legs testaceous; above pale fulvous; elytra closely punctured, a spot surrounding the scutellum and the apex, black. - Length 3 lines.

var. a. Scutellar spot absent.

var. $b$. Above reddish fulvous, the rest as in var. $a$.

Head impunctate, deeply transversely grooved between the eyes; frontal tubercles transverse; epistome impunctate, palpi subclaviform, fulvous; antennae half the length of the body, flavous, second and third joints very short, fourth joint the longest and much longer than the three preceeding ones united; thorax nearly three times as broad as long, the sides slightly rounded, anterior angles obliquely rounded, surface with a deep oblique depression at each side, impunctate; scutellum triangular, piceous; elytra widened towards the apex, closely and distinctly punctured, the punctures arranged in lines near the suture; a more or less broad, triangular shaped black spot is placed across the suture at the base, surrounding the scutellum, and another more elongate narrow spot at the extreme apex, extending in a point a short distance up the lateral margin; underside, posterior femora and tibiae black, anterior legs and tarsi fulvous; metasternum produced in a conical short protuberance between the intermediate legs; claws appendiculate.

The present insect differs from the typical form (E. $f a-$ viventris Baly) in the very long fourth joint of the antennae, the same joint in the last named species being only double the length of the preceeding; the elytra are also here less regularly punctate-striate; the other generic characters, especially the produced metasternum and the closed anterior coxal carities, are however all present and prove the insect to belong to the present genus, of which several species from China and India have been described by the author of the genus.

Notes from the Leyden Musoum, Vol. VI. 
Platyxantha (?) nigripennis, n. sp.

Below black; head and thorax rufous, disk of the latter obscure piceous, bifoveolate; antennae and legs fulvous; elytra black, finely and closely punctured. - Length $3^{1 / 2}$ lines.

Q (?). Below entirely fulvous.

Head impunctate, rather deeply triangularly depressed at the vertex; frontal tubercles transverse, bounded behind by a deep groove; carina acutely raised; labrum testaceous; penultimate joint of the palpi slightly thickened, terminal one short, conical; antennae sleuder, two thirds the length of the body, fulvous, the last joint piceous; second joint extremely short, third as long as the two preceeding united, the following subequal; thorax subquadrate, scarcely broader than long, the sides nearly straight at the base, rounded before the middle. and forming a broad angle; anterior and posterior angles acute but not produced, surface with an oblique moderately deep depression at each side, finely punctured within this depression, rest of the surface impunctate, rufous, the disk suffused with piceous; scutellum black; elytra slightly depressed below the base, the latter somewhat raised; surface very closely and finely punctured, the punctures arranged in indistinct rows, the basal and the apical portion nearly impunctate; elytral epipleurae continued to the apex; legs fulrous; tibiae unarmed; posterior first tarsal joint as long as the two following together; claws appendiculate; prosternum invisible between the thighs; anterior coxal cavities closed; 우 thorax more transverse.

I have for the present placed this insect in .Mr. Baly's genus Platyxantha on account of the closed coxal cavities, unarmed tibiae, appendiculate claws and subquadrate thorax; the author founded his genus on male specimens in which the posterior tibiae have curious appendages and the antennae are difformed; the female insects of the 3 species described are at present unknown. 
There are now 4 specimens contained in the present collection which I take to represent 2 males, from Banka (v. d. Bossche), and 2 females, from Serdang (Hagen); in the latter the thorax is more transverse, the abdomen as usual dilated and the colour of the underside and legs rariable, either fulvous or black; other structural differences I cannot find; should further material show that undoubted male insects are without the tibial appendages and have normal antennae but otherwise not differing from Platyxantha, as is the case with the present species, it would perhaps than be advisable for a better definition of Mr. Baly's genus, to place these insects in another or new genus.

Metrioidea Fairm. seems again to differ in having the third joint of the antennae but little longer than the second, while here it is about 4 times as long.

\section{Metrioidea (?), Fairm.}

M. Fairmaire has founded this genus on a species from the Fiji Islands; the characters given by the author agree so well with an insect contained in the present collection, that I must refer it to this genus, which must be included in Chapuis' 26th group, the Platyxanthinae; whether the species described there is rightly included in M. Fairmaire's genus, I am unable to say, not having seen the type of the latter.

\section{Metrioidea apicalis, n. sp.}

Oblong-ovate, black; antennae testaceous, the basal and apical joint piceous; thorax slightly broader than long, with a few fine punctures; elytra dark brown, shining, extremely finely geminate "punctate-striate. - Length 4$4^{1} /_{2}$ lines.

Head impunctate, shining, deeply transversely grooved between the antennae; frontal tubercles strongly raised, nearly contiguous; carina acute; clypeus transversely raised; palpi swollen and dilated, the terminal joint short,

Notes from the Leyden Museum, Vol. VI. 
conical; antennae two thirds the length of the body, slender, third joint double. the length of the second, fourth slightly longer than the preceeding; thorax one half broader than long, subquadrate, the sides rounded before the middle, narrowed near the base; anterior margin slightly concave, posterior one nearly straight; surface shining black with a few fine punctures irregularly placed; scutellum broad, its sides rounded, black; elytra wider at the base than the thorax, dilated behind the middle, chestnutbrown, very shining, the apex broadly black; disk extremely finely punctured, visible only under a strong lens, the punctures arranged in double widely distant rows; epipleurae broad, extending to the apex; tibiae unarmed; posterior first tarsal joint as long as the two following ones united; claws appendiculate; prosternum invisible, anterior coxal cavities closed; underside and legs black.

This insect is of a very shining appearance, the punctuation of its upper side being scarcely visible even under a lens; sometimes the labrum is fulvous at the sides, as. well as the last joint of the palpi; the latter are much swollen at the two terminal joints.

\section{Coeligetes, nor. gen.}

Body oblong; eyes large, subhemispherical, entire; antennae closely approached, filiform, the $2^{\mathrm{d}}$ joint short, third joint nearly 3 times as long; the following subequal; palpi rather robust, the terminal joint conical; thorax transverse, nearly three times as broad as long, of equal width, without depression; scutellum trigonate; elytra confusely punctured, parallel, their epipleurae disappearing below the middle; tibiae unarmed; posterior first tarsal joint as long as the two following ones united; claws appendiculate; prosternum invisible between the thighs; anterior coxal cavities closed.

$\sigma^{7}$. Fourth abdominal segment with a deep excavation, the ends produced into a point; fifth segment with a large and deep longitudinal cavity.

Notes from the Leyden Museum, Vol. VI. 
\%. Abdominal segments normal, the fifth emarginate at the apex.

This genus will enter the group of Platyxanthinae (the $26^{\text {th }}$ of Chapuis) from all genera of which it differs by the narrow transverse thorax and the want of depressions at the upper surface of the latter.

\section{Coeligetes submetallica, n. sp.}

Fulvous; head and thorax rather remotely but distinctly punctured; elytra metallic dark purplish or aeneous, closely punctured, the interstices finely rugose. - Length $31_{2}-4^{1} /_{2}$ lines.

var. Elytra testaceous, the sutural and lateral margin metallic purplish.

$\sigma^{7}$. Head finely punctured near the eyes, transversely grooved between the latter; frontal tubercles trigonate, nearly contiguous; lower part of face testaceous; antennae more than half the length of the body, testaceous, the two terminal joints obscure fuscous; thorax reddish fulvous, like the head, the anterior margin slightly concave, the sides somewhat rounded and narrowly margined, the angles produced in a short tubercle, the posterior ones furnished with a single bristle-like hair; surface rather convex, irregularly and remotely punctured; scutellum broad, its apex obtuse, black; elytra rather convex, closely and more distinctly punctured than the thorax, the interstices irregularly transversely and longitudinally rugose; underside fulvous; legs paler, the tibiae with a blackish streak at their outer side.

var. (Q). Larger and more robust, elytra testaceous, the lateral margin rather broadly, the sutural one very narrowly purplish blue as well as the extreme base.

The structure of the abdomen in the male of this species is very curious; the fourth segment is furnished with a small but deep cavity, the anterior margin of which is distinctly raised, while the posterior one is produced at 
each side in an acute point; the last segment is very long and also deeply excarated through its entire length, the sides ending in a point.

The female, which is much larger, is probably a variety; of the two males before me, one has the elytra of a dark bluish colour, the other represents a more intermediate stage in which the elytra show traces of the testaceous colour of the female with the exception of the margins which are as in the variety; no other differences are to be seen between the three specimens, which at first sight seem to represent different species.

\section{Aenidea sumatrensis, n. sp.}

Fulvous; breast and abdomen black; thorax nearly impunctate, biimpressed; elytra metallic green or blue, very closely punctured, the interstices obsoletely longitudinally costate. - Length $3-31 / 2$ lines.

$\sigma^{7}$. Front of the head excavated, $7^{\text {th }}$ joint of the antennae dilated at the apex.

Q. Antennae and head normal; thorax more transverse. var. Brenst and abdomen entirely fulvous.

$\sigma^{7}$. Head impunctate, deeply excavated in front, the excavation divided by a central ridge; third joint of palpi robust, dilated, the fourth short, acute; antennae two thirds the length of the body, the second joint very short, third longer than the fourth and as long as the seventh, the latter dilated at the apex, obliquely shaped at the same place; thorax subquadrate, slightly broader than long, the sides nearly straight, slightly narrowed below the middle, surface with a deep forea at each side, impunctate; angles slightly tuberculate, each tubercle with a single bristle-like hair; scutellum black; elytra parallel, metallic green or blue, closely punctured, the punctures arranged in irregular double or treble rows, the interstices obsoletely lqugitudinally costate.

The above description is drawn from a male specimen Notes from the Leyden Museum, Vol. VI. 
contained in my collection; in that of the collection of the Leyden Museum the antennae are wanting, but the insect agrees in every particular with my specimen; the female has a more transverse thorax and the depressions of the latter are less deep; the elytra are more distinctly costate; the clypeus is dirided at the middle by a longitudinal ridge, the sides being also excavated, but not the front as in the male; the antennae are simple and have the third, fourth and fifth as well as the two apical joints fuscous; the female and male insect contained in my collection (also from Sumatra) are black below; those collected by Dr. Hagen are fulvous.

London, July 1884. 